\title{
ORGANOGENESIS TANAMAN KACANG HIJAU (Vigna radiata L.) PADA BEBERAPA KONSENTRASI ZAT PENGATUR TUMBUH SITOKININ DAN GIBERELIN SECARA IN VITRO \\ Organogenesis of mung bean plants (Vigna radiata L.) on several growth regulator concentrations of cytokine and gibberellin in vitro
}

\author{
Sartia Hama* dan Lisa Widianti \\ Program Studi Agroteknologi, Fakultas Pertanian, Universitas Cokroaminoto Palopo, Palopo, Indonesia \\ Doi: 10.37195/jac.v1i2.75
}

*KORESPONDENSI

Telepon: +62-852-4204-2376

E-mail: sartiahamma@yahoo.com

\section{JEJAK PENGIRIMAN}

Diterima: 13 Jul 2019

Revisi Akhir: 27 Agu 2019

Disetujui: 31 Aug 2019

\section{KEYWORDS}

Mung bean plants, Growth regulators, In vitro

KATA KUNCI

Tanaman kacang hijau, Zat pengatur tumbuh, In vitro

\section{ABSTRACT}

This study aims to determine the organogenesis of mung bean plants (Vigna radiata L.) in several concentrations of cytokine and gibberellin growth regulators In Vitro. The method used was a Completely Randomized Design (CRD) with 6 treatments, 4 replications so that there were 24 experimental units. The concentration level used was $P 0=$ no treatment, $P 1=2.5 \mathrm{ppm} B A P+2 \mathrm{ppm} G A, P 2=3.5 \mathrm{ppm}$ $B A P+3 \mathrm{ppm} G A, P 3=4.5 \mathrm{ppm} \mathrm{BAP}+4 \mathrm{ppm} G A, P 4=5.5 \mathrm{ppm} B A P+5$ ppm GA, $P 5=6.5 \mathrm{ppm} B A P+6 \mathrm{ppm} G A$. The results showed that the growth regulator $B A P$ and $G A$ that given to each treatment had no significant effect on all parameters, this was due to the lack of elements of nitrogen to stimulate plant growth. The most effective treatment was found in P4 with a concentration $5.5 \mathrm{ppm} \mathrm{BAP+5ppm} \mathrm{GA} \mathrm{which} \mathrm{had}$ the average value of germination age of 2 days after planting, then the average value of plantlets height was $10.07 \mathrm{~cm}$, the average number of roots and number of leaves were as much as 2 strands, while the number of plantlet weight was 0.35 .

Penelitian ini bertujuan untuk mengetahui organogenesis tanaman kacang hijau (Vigna radiata L.) pada beberapa konsentrasi zat pengatur tumbuh sitokinin dan giberelin secara In Vitro. Metode yang digunakan dalam penelitian ini adalah Rancangan Acak Lengkap (RAL) dengan 6 perlakuan 4 ulangan sehingga terdapat 24 unit percobaan. Taraf konsentrasi yang digunakan $\mathrm{P} 0=$ kontrol (tanpa perlakuan), perlakuan $\mathrm{P} 1=2,5 \mathrm{ppm} \mathrm{BAP}+2 \mathrm{ppm}$ GA, $\mathrm{P} 2=3,5$ ppm $\mathrm{BAP}+3$ ppm GA, $\mathrm{P} 3=4,5$ ppm BAP +4 ppm GA, $\mathrm{P} 4=5,5$ ppm $\mathrm{BAP}+5$ ppm GA, $\mathrm{P} 5=6,5 \mathrm{ppm} \mathrm{BAP}+6 \mathrm{ppm}$ GA, pengamatan dilakukan dengan mengamati umur berkecambah (HST), tinggi tanaman (cm), jumlah akar (helai), jumlah daun (helai), bobot planlet (g). Hasil penelitian menunjukan bahwa pemberian zat pengatur tumbuh BAP dan GA yang diberikan pada masing-masing perlakuan tidak berpengaruh nyata terhadap semua parameter, hal ini disebabkan karena kurangnya unsur nitrogen untuk memacu pertumbuhan tanaman. Perlakuan yang paling efektif terdapat pada $\mathrm{P} 4$ dengan konsentrasi 5,5 ppm BAP +5 ppm GA, dengan nilai rata-rata umur perkecambahan 2 hari setelah tanam, kemudian nilai rata-rata tinggi planlet yaitu $10,07 \mathrm{~cm}$, rata-rata jumlah akar dan jumlah daun yaitu sebanyak 2 helai sedangkan jumlah bobot planlet yaitu 0,35. 


\section{PENDAHULUAN}

Tanaman kacang hijau (Vigna radiata L.) merupakan salah satu tanaman pangan sumber protein nabati. Kandungan protein kacang hijau sebesar 22\% menempati urutan ketiga setelah kedelai dan kacang tanah (Purwono \& Hartono, 2005). Kacang hijau sangatlah bermanfaat bagi tubuh manusia karena selain mengandung protein, karbohidrat, lemak dan kalsium, juga mengandung beberapa vitamin. Menurut Rukmana (1997) dalam 100 g kacang hijau mengandung protein sebesar 22,00 g, lemak $1,20 \mathrm{~g}$, karbohidrat $62,90 \mathrm{~g}$, air $10,00 \mathrm{~g}$, kalsium 125,00 $\mathrm{mg}$, vitamin A 57,00 $\mathrm{mg}$, vitamin B 0,64 mg dan vitamin $C$ sebesar 6,00 mg. Produksi kacang hijau di Indonesia masih tergolong rendah, yaitu mencapai 0,78 ton/ha, sedangkan rata-rata produksi varietas unggul yang dianjurkan baru mencapai sekitar 1,6 ton/ha, padahal pada kondisi lingkungan yang baik hasil kacang hijau dapat mencapai 2.500$2.800 \mathrm{~kg} / \mathrm{ha}$ (Soemarno, Sutama, \& Soegito 1989; Soeprapto, 1993).

Kacang hijau memiliki permintaan produksi yang sangat tinggi setiap tahunnya, namun hal ini tidak sebanding dengan produksi kacang hijau yang terus mengalami penurunan disebabkan oleh jumlah bibit yang terbatas. Teknik budidaya yang baik dan tepat menjadi salah satu cara untuk meningkatkan produksi tanaman kacang hijau. Salah satu upaya untuk meningkatkan pertumbuhan dan produksi tanaman kacang hijau adalah dengan teknik kultur jaringan. Kultur jaringan merupakan suatu metode untuk mengisolasi bagian dari tanaman untuk memperbanyak jumlah bibit kacang hijau dalam waktu yang singkat. Menurut Gunawan (1987) kultur jaringan merupakan salah satu cara perbanyakan tanaman secara vegetatif. Kultur jaringan merupakan salah satu cara perbanyakan tanaman dengan cara mengisolasi bagian-bagian atau organ tanaman seperti kalus, daun, mata dan tunas, untuk dikembangkan dalam media buatan yang aseptik dan penambahan nutrisi dan zat pengatur tumbuh pada wadah tertutup sehingga bagian tanaman dapat memperbanyak atau menggandakan diri dan bergenerasi menjadi tanaman lengkap yang memiliki akar, batang dan daun.

Dalam proses kultur jaringan ini perlu penambahan senyawa organik tetapi bukan nutrisi yaitu zat pengatur tumbuh. Hendaryono dan Wijayani (1994) menyatakan bahwa, zat pengatur tumbuh (ZPT) merupakan hormon sintetis dari luar tubuh tanaman. Zat pengatur tumbuh memiliki fungsi untuk merangsang perkecambahan, pertumbuhan akar dan tunas. Zat pengatur tumbuh terbagi atas beberapa macam antara lain auksin, sitokinin dan giberelin. Bahan aktif yang mengandung auksin alami antara lain Indol Asam Asetat (IAA), Indol Asam Butirat (IBA) dan untuk auksin sintetik yaitu Naftalen Asam Asetat (NAA), dan 2,4 D Dikhlorofenoksiasetat $(2,4$ D). Bahan yang mengandung sitokinin alami yaitu air kelapa, jagung muda dan bonggol pisang sedangkan zat pengatur tumbuh sitokinin sintetik antara lain N6-Benziladenin (N6-BA). Demikian rebung dan bawang merah tekandung giberelin alami.

Berdasarkan masalah yang dihadapi dalam pengembangan kacang hijau adalah masih rendahnya produksi yang dicapai petani. Rendahnya hasil disebabkan oleh budidaya yang kurang baik, terbatasnya ketersediaan bibit unggul, adanya serangan penyakit dan virus. Adapun tujuan pada penelitian ini adalah 1) mengetahui pengaruh zat pengatur tumbuh sitokinin dan giberelin terhadap organogenesis tanaman kacang hijau dan 2) mengetahui berapa konsentrasi zat pengatur tumbuh sitokinin dan giberelin yang efektif terhadap organogenesis tanaman kacang hijau secara in vitro.

\section{BAHAN DAN METODE}

\section{Bahan}

Bahan-bahan yang digunakan dalam penelitian ini adalah benih bina bermutu tinggi; gula putih; air kelapa; aquades steril; agar-agar putih (Swallow Globe) diproduksi oleh PT. Dunia Bintang Walet, Jakarta, Indonesia; zat pengatur tumbuh sitokinin yaitu BAP dan Giberelin yaitu GA diproduksi oleh PT. Indo Biotech Agro, Jawa Timur, Indonesia; alkohol 70\%; alkohol 96\%; spirtus; klorox (Bayclean) diproduksi oleh PT. Tanshania Consumer, Jakarta, Indonesia. 


\section{Desain Penelitian}

Penelitian ini menggunakan Rancangan Acak Lengkap (RAL), yang terdiri dari 6 perlakuan yang diulang sebanyak 4 kali sehingga terdapat 24 unit percobaan. Adapun percobaannya, yaitu:

$\mathrm{P} 0=$ Media MS + 0 ppm BAP + 0 ppm GA

(Kontrol)

$\mathrm{P} 1=$ Media $\mathrm{MS}+2,5 \mathrm{ppm} \mathrm{BAP}+2 \mathrm{ppm}$ GA

$\mathrm{P} 2=$ Media $\mathrm{MS}+3,5 \mathrm{ppm} \mathrm{BAP}+3 \mathrm{ppm}$ GA

$\mathrm{P} 3=$ Media $\mathrm{MS}+4,5 \mathrm{ppm} \mathrm{BAP}+4 \mathrm{ppm} \mathrm{GA}$

$\mathrm{P} 4=$ MediaMS $+5,5 \mathrm{ppm} \mathrm{BAP}+5 \mathrm{ppm} \mathrm{GA}$

$\mathrm{P} 5=$ Media MS + 6,5 ppm BAP + 6 ppm GA

Data pengamatan kemudian dianalisis menggunakan sidik ragam (Analisis Sidik Ragam), selanjutnya data diuji dengan beda nyata jujur (BNJ) pada taraf $5 \%$.

\section{Sterilisasi Alat Tanam}

Pada tahap sterilisasi alat tanam, pertama-tama dilakukan pencucian botol dengan menggunakan sabun cuci piring dan dibilas dengan air bersih. Setelah itu botol direndam menggunakan baskom yang berisi klorox dan air selama 24 jam, kemudian ditiriskan pada keranjang. Lalu botol-botol tersebut disusun dengan rapi ke dalam autoklaf untuk sterilisasi botol, setelah itu autoklaf tersebut ditutup rapat, kemudian skruf autoklaf diputar sekeras mungkin dengan berlawanan arah. Autoklaf kemudian dinyalakan dan ditunggu hingga mengeluarkan uap pada salah satu tutup klep autoklaf, dan segera dilakukan perhitungan lamanya penguapan sterilisasi botol (30-45 menit, dengan suhu $121^{\circ} \mathrm{C}$ ). Botol yang telah disterilkan kemudian dikeluarkan dan disimpan pada lemari kaca steril dan bebas dari debu. Kemudian sterilisasi cawan petridis, pinset, scalpel dibersihkan dengan menggunakan sabun cuci kemudian dibilas dan ditiriskan, setelah ditiriskan dibungkus dengan kertas, kemudian dimasukan dalam autoklaf. Setelah semua alat tanam steril, kemudian disimpan di dalam lemari kaca yang sudah steril dan bebas dari debu.

\section{Pembuatan Media}

Media tanam merupakan salah satu bahan terpenting dalam proses kultur jaringan. Pada pembuatan media tanam, dimulai dengan penyiapan bahan-bahan dan alat yang diperlukan, seperti gelas ukur, gula putih, agar-agar putih dan $\mathrm{pH}$ meter, setelah itu agar-agar $3,5 \mathrm{~g}$, dan gula $15 \mathrm{~g}$ ditimbang, kemudian dosis masing-masing stok diukur sesuai dengan dosis penelitian. Kemudian air kelapa sebanyak $50 \mathrm{ml}$ dan aquades sebanyak $500 \mathrm{ml}$ dimasukkan ke dalam gelas ukur untuk pembuatan media MS. Kemudian semua bahan dicampur menjadi satu dan dilakukan pengukuran $\mathrm{pH}$ terlebih dahulu sebelum dipindahkan panci kecil. Setelah $\mathrm{pH}$ diukur, maka siap untuk dimasak hingga mendidih dan siap untuk dimasukkan ke dalam botol steril lalu ditutup menggunakan aluminium foil.

\section{Pengambilan Eksplan dan Sterilisasi Eksplan}

Eksplan yang digunakan adalah biji kacang hijau. Pengambilan eksplan dilakukan dengan memilih biji kacang hijau yang memiliki kualitas bagus yang terhindar dari hama dan penyakit. Proses sterilisasi eksplan dilakukan dengan cara mencuci biji tersebut menggunakan fungisida selama 20 menit, kemudian ditiriskan. Setelah itu, eksplan kemudian direndam menggunakan aquades selama 20 menit. Setelah 20 menit, biji kacang hijau kembali disterilkan pada LAF (Laminar Air Flow) dengan cara merendam kembali dengan air steril sebanyak 3 kali, dengan durasi perendaman masing-masing 5 menit. Proses pencucian dilakukan dengan cara memasukkan biji kacang hijau ke dalam gelas dan diberi air steril kemudian dilakukan perendaman selama 5 menit, setelah itu air rendaman dibuang dan diganti dengan air baru, lalu kemudin diaduk kembali. Setelah bersih, biji kacang hijau tersebut diletakkan pada cawan petri steril. Cawan petri diisi, ditutup, dan kemudian didiamkan selama beberapa menit sebelum eksplan siap untuk ditanam.

\section{Inokulasi/Penanaman}

Penanaman eksplan pada tempat steril dilakukan dengan mengambil eksplan, kemudian diletakkan di atas cawan petri. Eksplan kemudian diambil menggunakan pinset dan dimasukkan ke dalam botol dan ditutup rapat menggunakan aluminium foil.

\section{Variabel Pengamatan}

Pengamatan dilakukan setelah tanaman berkecambah dan pengamatan berikutnya 
dilakukan setelah tanaman tumbuh (sesuai dengan variabel pengamatan). Ada beberapa variabel pengamatan yang diamati dan diukur dalam penelitian ini yaitu, umur berkalus (hari setelah kultur), tinggi planlet (cm), jumlah akar (helai), jumlah daun (helai), bobot planlet $(g)$.

\section{HASIL DAN PEMBAHASAN}

\section{Umur Berkecambah}

Hasil penelitian menunjukan bahwa konsentrasi zat pengatur tumbuh BAP dan GA memiliki hasil yang sama pada parameter umur berkecambah tanaman kacang hijau. Hasil penelitian menunjukkan bahwa, pada semua perlakuan menghasilkan umur berkecambah tanaman kacang hijau paling cepat 2 hari setelah tanam. Hal ini disebabkan karena eksplan pada kacang hijau lunak sehingga proses perkecambahan sangat cepat. Kecambah adalah biji-bijian yang mengalami perubahan fisik dan kimiawi yang disebabkan oleh proses metabolisme. Menurut Salisbury dan Ross (1995), metabolisme adalah reaksi kimia yang memungkinkan adanya kehidupan dalam proses pertumbuhan.

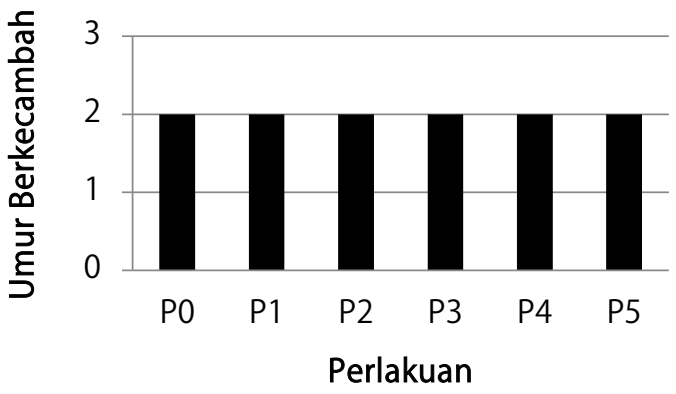

Gbr 1. Diagram umur berkecambah tanaman kacang hijau

\section{Tinggi Tanaman}

Hasil rata-rata tinggi tanaman kacang hijau dengan pemberian zat pengatur tumbuh BAP dan GA menunjukkan nilai yang berbedabeda dan konsentrasi yang berbeda-beda pada parameter tinggi tanaman (Gbr. 2). Pengaruh pemberian zat pengatur tumbuh BAP dan GA terhadap tinggi tanaman yang paling baik ditunjukkan oleh perlakuan P4 (5,5 ppm BAP + 5 ppm GA) dengan nilai rata-rata tinggi tanaman 10,07 cm, sedangkan yang terendah terdapat pada perlakuan $\mathrm{P} 1$, dengan nilai rata-rata 7,25 cm. Pemberian giberelin dengan



Gbr 2. Diagram tinggi tanaman kacang hijau

konsentrasi tertinggi dapat mempengaruhi tinggi tanamandimana giberelin dapat memacu tanaman mencapai tinggi yang maksimal. Hal ini sesuai dengan pendapat Prawiranata, Harran, dan Tjondronegoro (1981), yang menyatakan bahwa, GA (giberelin) dapat memacu pertumbuhan batang dan meningkatkan pembesaran dan perbanyakan sel pada tanaman, sehingga tanaman dapat mencapai tinggi yang maksimal, sedangkan BAP (sitokinin) dapat memacu pembelahan sel.

\section{Jumlah Daun}

Hasil penelitian menunjukan bahwa konsentrasi zat pengatur tumbuh BAP pada parameter jumlah daun tanaman kacang hijau memperlihatkan hasil yang sama. Hasil ratarata jumlah daun tanaman kacang hijau tersebut dapat dilihat pada Gbr 3.

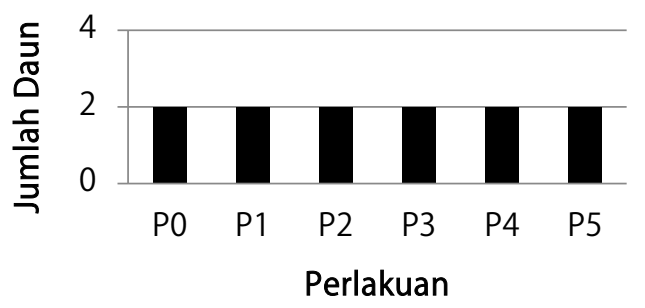

Gbr 3. Diagram jumlah daun tanaman kacang hijau

Berdasarkan hasil penelitian pada diagram jumlah daun yang disajikan pada Gbr. 3, proses pembentukan daun yang terbentuk yaitu sebanyak 2 helai. Karena proses pertumbuhan eksplan kacang hijau sangat cepat, sehingga pembentukan daunpun sangat cepat. Selain itu juga eksplan kacang hijau sangatlah lunak, dan tingginya kadar unsur hara tersedia dapat memacu aktivitas hormon dalam pembentukan daun. Hal ini sesuai dengan pendapat Goldsworthy dan Fisher (1992) yang mangatakan bahwa, 
pembentukan daun dipengaruhi oleh banyaknya rangsangan hormon.

\section{Jumlah Akar}

Analisis sidik ragam menunjukkan bahwa untuk setiap perlakuan memperlihatkan hasil atau nilai yang sama, akan tetapi terdapat nilai yang berbeda-beda, yang ditunjukkan pada perlakuan pemberian konsentrasi zat pengatur tumbuh BAP dan GA pada variable pengamatan jumlah akar tanaman kacang hijau.

Pengaruh pemberian zat pengatur tumbuh BAP dan GA terhadap jumlah akar terbanyak terdapat pada P0 (tanpa perlakuan) dengan nilai rata-rata $2,75 \mathrm{~cm}$, sedangkan terendah ditunjukkan oleh perlakuan P1(2,5 ppm BAP + 2 ppm GA), P2 (3,5 ppm BAP + 3 ppm GA), P3 (4,5 ppm BAP + 4 ppm GA) dan P5 (6,5 ppm BAP + 6 ppm GA) dengan nilai rata-rata $1 \mathrm{~cm}$. Pemberian zat pengatur tumbuh BAP dan GA tidak memberikan respon yang baik sehingga jumlah akar pada tanaman kacang hijau sangat sedikit, sedikitnya jumlah akar kemungkinan disebabkan oleh kurangnya air dan mineral yang tersedia dalam media MS. Hal ini sesuai dengan pendapat, Gardner, Pearce dan Mitchell (1991) bahwa, akar merupakan organ vegetatif utama yang memasok atau alat transportasi dalam proses penyerapan air dan mineral untuk pertumbuhan dan perkembangan tanaman, serta menjadi faktor yang sangat penting dalam menyerap unsurunsur yang terdapat dalam media kultur.

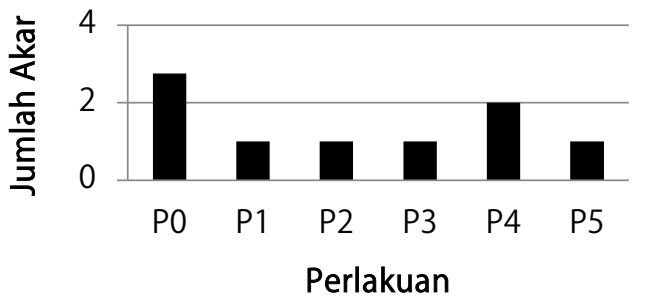

Gbr 4. Diagram jumlah akar tanaman kacang hijau

\section{Bobot Planlet}

Pemberian zat pengatur tumbuh BAP dan GA menunjukkan hasil yang yang berbedabeda pada setiap perlakuan. Hasil rata-rata diameter bobot planlet dapat dilihat pada $\mathrm{Gbr}$ 5. Hasil analisis sidik ragam pada parameter bobot planlet yang paling baik terdapat pada perlakuan P2 (3,5 ppm BAP $+3 \mathrm{ppm} \mathrm{GA})$ dengan rata-rata 0,38 gram, sedangkan hasil terendah ditunjukkan oleh perlakuan $\mathrm{P} 0$ yaitu 0,24 gram, dibandingkan dengan perlakuan lainnya. Pemberian zat pengatur tumbuh BAP dan GA dapat mendukung pertumbuhan

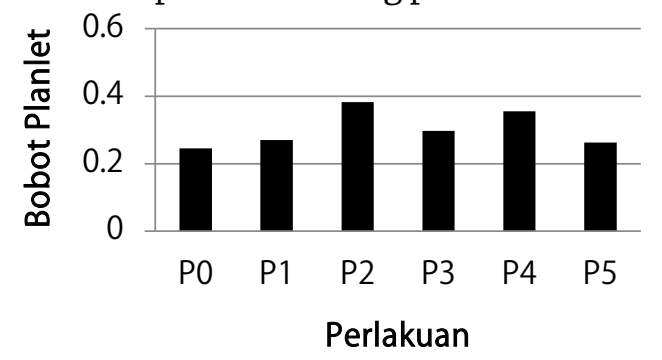

Gbr 5. Diagram bobot planlet tanaman kacang hijau

tanaman kacang hijau sehingga meningkatkan pertambahan bobot planlet kacang hijau tersebut. Utama (2015) menyatakan bahwa, pemberian zat pengatur tumbuh sitokinin pada eksplan tanaman kacang hijau membantu proses pembelahan sel sehingga ukuran, bentuk, dan volume planlet akan bertambah besar, dan penambahan giberelin pada eksplan tanaman kacang hijau juga akan memberi pengaruh dalam merangsang pembesaran sel.

\section{KESIMPULAN}

Pemberian zat pengatur tumbuh BAP dan GA dengan berbagai konsentrasi memperlihatkan hasil yang berbeda-beda dan tidak berpengaruh terhadap semua parameter pengamatan yang terdiri dari umur berkecambah, tinggi tanaman, jumlah daun, jumlah akar, dan bobot planlet tanaman kacang hijau. Konsentrasi yang paling efektif ditunjukkanoleh perlakuan P4 (5,5 ppm BAP + 5 ppm GA) yaitu dengan nilai rata-rata umur perkecambahan 2 hari setelah tanam, nilai rata-rata tinggi planlet yaitu $10,07 \mathrm{~cm}$, ratarata jumlah akar dan jumlah daun yaitu sebanyak 2 helai, sedangkan jumlah bobot planlet yaitu $0,35 \mathrm{~g}$.

\section{DAFTAR PUSTAKA}

Gardner, F. P., Pearce, R. B., \& Mitchell, R. L. (1991). Fisiologi Tanaman Budidaya. ( Alih bahasa oleh H. Susilo \& Subyanto). Jakarta: UI-Press.

Goldsworthy, P. R., \& Fisher N. M. (1992). Fisiologi Tanaman Budidaya Tropik. (Alih bahasa oleh Tohari). Yogyakarta: Penerbit Gadjah Mada University Press. 
Gunawan, L. W. (1987). Teknik Kultur Jaringan Tumbuhan. Bogor: Laboratorium Kultur Jaringan Tanaman, PAU Bioteknologi, IPB Bogor.

Hendaryono, D. P. S., \& Wijayani, A. (1994). Teknik Kultur Jaringan: Pengenalan dan Petunjuk Perbanyakan Tanaman secara Vegetatif-Modern. Yogyakarta: Penerbit Kanisius.

Purwono, \& Hartono, R. (2005). Kacang Hijau. Jakarta: Penebar Swadaya.

Prawiranata, Harran, W. S., \& Tjondronegoro, P. (1981). Dasar-dasar Fisiologi Tumbuhan II. Bogor. Fakultas Pertanian IPB.

Rukmana. (1997). Ubi Jalar-Budidaya dan Pasca Panen. Yogyakarta: Penerbit Kanisius.

Salisbury, F. B., \& Ross, C. W. (1995). Fisiologi
Tumbuhan (Jilid 3, Diterjemahkan oleh Diah R. Lukman \& Sumaryono). Bandung: Penerbit ITB.

Soemarno, F., Sutarman, T., \& Soegito, J. S. (1989). Grain legume breeding for wetland and for acid soil adaptation: final report of project legume varietal selection for condition after lowland rice and for acid soil (Phase I). Central Research Institute for Food Crops, 1984-1988.

Soeprapto, H. S. (1990). Bertanam Kacang Hijau. Jakarta: Penebar swadaya.

Utama, M. Z. H. (2015). Budidaya Padi pada Lahan Marginal: Kiat Meningkatkan Produksi Padi. Yogyakarta: CV. Andi Offset. 